\title{
The East Lost the Cold War, but did the West Win?
}

\author{
Curtis Bauer
}

Clearly the East lost the Cold War to the West, suffering total economic and political collapse by the late 1980s. Yet it is not entrirely clear if or what the West won. Western economies continue to labor under the extensive military commitments. The ideology of liberal democracy, although laudable, is difficult to implememt. Capitalism, as an economic system, is tom between the need for perpetual growth and the protection of a fragile environment. Was the end of the Cold War truly "the end of history" as some suggest, or do the lessons of the period stand instead as a cautionary for the future?

\section{Introduction}

There is no question that the East lost the Cold War to the West, but did the West win? The attempted reforms of Gorbachev could not prevent the economic and political collapse of the former USSR and were, in effect, a concession of defeat. However, as the euphoria of victory began to subside, the toll of decades of hostility on Western Europe and North America was revealed. Economies remain burdened by institutionalized military spending. The process of decolonization and the realignment of alliances continue to erode Western dominance. Western sociely remains far from the yearnedfor ideals of liberal democracy. Capitalism is caught between the demand for unlimited growth and the limited capacity of the environment to sustain it.

\section{The East lost the Cold War}

Although it often involved opponents in military conflict, the Cold War was primarily an economic and political battle between East and West. From the point of view of the United States, the breakdown of the USSR was a victory for the policy of containment, as defined by George Kennan in 1946. This policy stated that the most economical way of defeating Russia was to hold it in its current 
geopolitical situation while patiently waiting for it to "progress" towards capitalistic democracy on its own terms. " Although it took longer than expected, the forty year policy of containment is often cited as the main reason for the downfall of Communism: it prevented Communist expansion while allowing time for the internal contradictions of the system to destroy it. ${ }^{2}$

Gorbachev's altempts to revive the stagnant economy were undermined by the corruption and inefficiency. He had inherited a centralized economy that could simply not compete with Western productivity. For example, the gross domestic product (GDP) of West Germany, small in terms of territory and resources (and equally devastated after World War Two) exceeded the Soviet GDP by the $1980 \mathrm{~s}^{3}$ Particularly burdensome were the large military expenditures, estimated to have consistently consumed around $15 \%$ of the GDP. ${ }^{4}$ American President Ronald Reagan's Strategic Defense Initiative (SDI) exposed a Soviet cconomy at the breaking point, unable to increase military spending any further. 5

Confronted with massive problems, Gorbachev proposed an easing of international tensions coupled with a restructuring of the economy (Perestroika). The easing of tensions was successful, but the Soviet economy continued to carry budget deficits throughout the latter half of the 1980s due, in part, to an unfavorable trade balance. 6 Gorbachev attempted to form a "Common European Home" of European states to resist US economic dominance but failed to attract interest. ${ }^{7}$ It was becoming clear that Perestroika was also failing, as the centralized economy, mired in corruption, continued to produce goods poor in quality and short in supply. ${ }^{8}$ Ultimately, the economic triumph of the West was acknowledged when Gorbachev admitted that the Soviet Union was surrounded not by superior armies but by

I Von Lare. T.K., Why Lenin? Why Stalin? Ithy Gorbache? (New York: HaperCollins, 1993), p. 182.

2 Kissinger. H. Diplonacy (New York: Simon and Schuster, 1994), p. 802.

3 Kennedy, P., Proparing for the Tweeny-First Cenury (Torotso: JlaperCollins, 1993), p. 2.34.

4 Mazower, M. Dark Continent: Europe's Tweruirth Century (New York: Vintage Books, 1998), p. 369.

5 lbid., p. 378.

6 The Satesman s Jienr-Book 1281h Edision 199/-92, edited by Brian Hunter (1.sadon: The Macinillan Press, 1991).

p. 1239.

7 Gorbactev, M. Menoirs (New York: Doubleday, 1995). p. 429.

8 Mazower. p. 364. 
superior economies. ${ }^{9}$

Forty years of containment had also left the USSR's foreign policy politically inert. Gorbachev's "new thinking" in foreign policy was meant to break through the ring of enemies with overtures of peace and non-intervention, but this only removed the threat of Soviet military intervention. While the Soviet pull out from Afghanistan was a step towards positive relations with the West and China, it simultaneously exposed the Red Army's inability to subdue even a third-world nation located on its own doorstep. When it became apparent that Gorbachev would no longer interfere militarily in Eastern Europe, former client states, in effect, defected, attempting to join the EEC and NATO for economic and political security. These defections culminated in the admission of a united Germany to NATO in 1990. Other client states, including Cuba, North Korea, Vietnam, Libya, Ethiopia, and Yemen sensed weakness and began looking for new allies. ${ }^{10}$ The marginalization of the USSR during the 1991 Gulf War was an indication of how far its international stature had fallen." The cumulative effect of these changes of allegiance were important in creating the perception of the USSR as the loser of the Cold War in the eyes of the world. ${ }^{12}$

At the same time, numerous contradictions were revealed between the current practices and the original ideals of communism. The socialist aspirations of workers owning the means of production stood in sharp contrast with the stratification and privileges of Soviet society. Disillusioned communists, such as Milovan Djilas (a high ranking Yugoslav party boss), began to loose faith as early as the 1950s, when they realized that Communist society was becoming less rather than more egalitarian. ${ }^{13}$ By the 1980 s the special privileges of the nomenklatura, or top party members, had so distorted communism, that the Solidarity trade union was formed to represent

9 Von I aue, p. 166.

10 D'Agostino, A. Corbarhev's Revolusion (New York: New York Univensity Press, 1998), p. 290.

11 thid.. p. 293.

12 bid., p 220.

13 Djilas, M. "The New Class" From Salinisen so Plurdion. edited by (bite Stokes (Nen York: Oxford University Press. 19961. pp. 101-106. 
workers against the state. Gorbachev sought to return to the worker's democracy envisioned by Marx and Lenin, but the nomenklatura were 100 firmly entrenched and sidestepped these efforts at reform. ${ }^{14}$

The environment as well as the economy suffered under Communism. As envisioned by Stalin and his successors, the environment was merely a place in which to situate massive industrial projects. Nowhere was it acknowledged that there must be limits to such growth. This may be the natural result of an ideology that was, in essence, overwhelmingly technologically deterministic, promising that happiness could be achieved through material sufficiency. ${ }^{15}$ The disaster at Chernobyl in 1986 exposed the limitations of Communist ideology with respect to environmental matters. The ramifications of Chernobyl are still being felt, and are contributing in no small part to the stunting of political and economic growth in Belarus and the Ukraine. ${ }^{16}$

\section{But did the West Win the Cold War?}

Capitalism may have triumphed as an economic system, but the end of the Cold War exposed many challenges previously obscured by the simplifications of a bi-polar world. The Cold War required perpetual readiness for war, and the resulting emphasis on military spending can be seen to have damaged or at least distorted Western economies. It has been speculated that empires, regardless of ideological affiliation, collapse when military expenditures outstrip the economic capacity necessary to sustain them. ${ }^{17}$ Much is made of the impact of SDI on the Soviet economy, but in the four years of Reagan's presidency the United States went from the world's largest creditor nation to the world's largest debtor nation. ${ }^{18}$ Indeed, the decline in America's GDP growth rates from the 1940s to the

14 Wun Iave, p.167.

I5 Winner. La. "Techne and t'oliteria: The Technical Constituitun of Society" Trcheology as a Ihanan Affair edited by Lam A. Hichnan (New York: AcGran Hill. 1990). p.+11. Tectingotogical deteninism is the strong belief that technotogy equals progress.

I6 Maples, D.R., Belarws: From Sovirt Rule to Nuclear Cusastrophe (lidnonton: The Universily of Alberta Press. 1996). pn. 48-80.

17 Kennedy. B. The Rise ard Fall of the Great Powers (L endon: Unuin Hyman, 1988), p.439.

18 Kennedy, Preparing for the Twent) Firzl Certury. p.298. 
1990 s closely parallels that of the USSR for the same time period. ${ }^{19}$

Since military goods are non-capital (that is, they can not be used to creale wealth), the massive Cold War expenditures may have acted as a drag on the American economy. This can be seen by comparing the post-World War Two economic rise of Japan and West Germany with the United States. With constitutions forbidding remilitarization, these nations were free to concentrate on capital goods. After World War Two, America accounted for $50 \%$ of world GDP, whereas by 1991 it accounted for only twenty-three percent. ${ }^{20}$

The decades long threat of Cold War allowed the militaryindustrial complex to became embedded in American political and economic systems. ${ }^{21}$ The war is over, but relief from the military burden remains out of sight. Western militaries seem to have found a new raison d'être in humanitarian missions. ${ }^{22}$ The post-Cold War period has seen a rapid increase in peacekeeping interventions: from 1945 to 1987 there only were thirteen peacekeeping missions. whereas from 1987 to 1993 there were twenty-one. ${ }^{23}$ While such missions may be important in keeping international order, the political crosscurrents inherent in them are often troubling. Former Cold War allies, such as Manuel Noriega and Saddam Hussein, suddenly became the enemy of America when foreign policy went into rapid reversal. ${ }^{25}$ Moreover, there appears to be no abatement in weapons development in the post-Cold War world. The five members of the UN Security Council accounted for eighty-six percent of total world trade in arms in 1992.26 Science (or, as some say, technoscience) continues its affiliation with federal research monies, a large proportion of which are still devoted to weapons

19 bid. p.295.

20 Iendestad, $\mathbf{i}$ The End of the Cold War. the New Rote for Europe, and Ite Decline of the United Slates" in The End of he Cold War, adited by M.J. Hogan (New York: Cambridge University Press, 1992 b. p. 200.

21 Clxomsky. The New Mfilitary Ulamanitariarim (Vancouver. New Siar Books, 1999), p. 138; Chomsky. Drierring Drmarary, p.24.

22 Chombly. N.. The Nen Milinary Itumanitorianism, p.4.

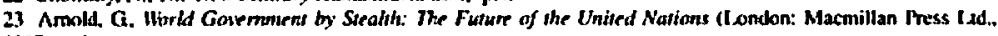
1997. p.I.

24 Amold p.I.

25 Chomsky. N. Detering Demacracy (New Vork: Versa 1991) p.28.

26 Armold p.146. 
development. ${ }^{27}$

In a larger political sense, the end of the Cold War can be seen as the end of the colonial era. ${ }^{28}$ The weakening effects of World War One, World War Two and the Cold War accelerated the processes of decolonization. ${ }^{29}$ The increasing sophistication of guerilla warfare, as witnessed in Vietnam and Afghanistan, made the costs of occupation too high in economic, political and human terms. The process of decolonization encouraged new regional alliances to form, resulting in a global identity crisis of sorts in former colonial territories where new identities are being forged, often on a tribal or religious basis. Thus the Soviet withdrawal from Afghanistan was not a triumph for the "Free World", but a victory for certain Afghani Muslims. ${ }^{30}$ In a similar way, the end of Cold War bi-lateralism has allowed a united Europe to emerge and redefine itself as an entity distinct from both the United States and Russia. ${ }^{31}$

Western ideology also faces new challenges. In 1992 the end of the Cold War was proclaimed as the 'end of history' and the triumph of liberal democracy over Communism was celebrated. ${ }^{32}$ In practice, however, ideologies fall short of their lofty ideals. In Western society, it can be claimed that democracy is actually controlled by elite oligarchies through subtle control of the media and the political process. ${ }^{33}$ Capitalism (as currently practiced) becomes a willing collaborator by creating managers and workers (not owners) who, fearful of losing their positions and salaries, do not question the status quo. ${ }^{34}$ The dominant political and economic institutions in the West are stable and subject to few internal challenges, just as their Soviet counterparts had been. ${ }^{35}$ In such a situation, Western societies are in constant danger of excessive stratification: by the mid $1990 \mathrm{~s}$,

\footnotetext{
27 Gray, C.H. Postmodem Har: The Nen Politics of Conflics (New Yorh: The Gujlford Press. 1997). p.225.

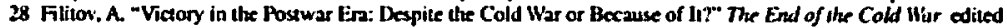
by M.J.Hogan (New York: Combridge Universily Press, 19921. pp. 77.86 .

29 Mazower, p.376.

30 lluntington, p.247.

31 Huntington. p.145. Kennedy. Prejuring for the Turenty.First Century. p.270.

32 Fuhuyama. F. Mtr End of Hiutory and the lau Mon (New York: The Iree Press, 19921. p. xi.

33 Mantufarturing Consent. Noan Chomsky, Natiunal Film toand of Canada. 1992.

34 Saul, I.R. Iblhain's Bastants: The Dictatorship of Reason in the Whst (Toronto: Viking. 19922. pp. 358.393.

35 Chonsky, Deterring Demecracy: p.59.
} 
the top $1 \%$ of American rich owned approximately $40 \%$ of the nation's wealth. ${ }^{36}$ The consequences of this stratification have yet to become clear.

As for the environment, Western ideology has yel to come to grips with the paradox of destructive growth. Many decry unbridled capitalist practices that result in environmental degradation on a global scale, yet Western societies continue to demand economic growth. ${ }^{37}$ The current Western penchant for turning wants into needs often relegates the environment to secondary consideration (i.e. witness the current popularity of sport utility vehicles). The march of capitalism into Russia has not relieved the environmental burden left behind by Communism, and may have even aggravated the problem. $^{38}$

\section{Conclusion}

Insofar as the Cold War pitted East against West, economic and political collapse of the USSR in the 1980s left the West "the last man standing" and the apparent victor of the struggle. The centralized Soviet economy could not reform itself. Continued political isolation reduced the Soviet Union to regional power status. Communism failed to deliver on the promise of material well-being and the environment was degraded. Yet it is not entirely clear if the West should be declared triumphant. The West too was forced to labor under expensive military commitments. The institutions necessitated by perpetual readiness for war continue to distort the economy. The rejection of Western hegemony continues, while the goal of liberal democracy remains elusive. Capitalism, as an economic system, is torn between the need for perpetual growth and the protection of a fragile environment. The end of the Cold War has been cleclared the

\footnotetext{
36 Calleo. D. "Annerican Reactions to the End of the Cold Wis" The Fall of the Sovir Empire ratital by Anne De Tinguy (New York: Columbia University Press 1947). p.4Jy. 37 Kennedy, Preparing for the Thrnty-First Centan; p.98. 38 Chomsly. Deterring Democrary, p.61; The infamous ' $\%$ ' document in the American Acadeny af Arts and Science (1990) assunted the spread of capitalism in Russia was the solution to all ber problems. despite no supponing historical evidence.
} 
"end of history", however, it is clear that the legacies of this time continue to impact the present and are likely to influence the future for years to come. 